\title{
EFFICIENCY OF THE TREATMENT OF CATS WITH DYSHORMONAL DYSPLASIA OF THE MAMMARY GLAND
}

Zayakina Darya Igorevna, Veterinarian Resident Doctor of the chair "Obstetrics, Surgery and Physiology of Pets", Don State Agrarian University. Russia.

Voitenko Lyubov Gennedyevna, Doctor of Veterinarian Sciences, Professor, Head of the chair "Obstetrics, Surgery and Physiology of Pets", Don State Agrarian University. Russia.

Keywords: cats; dyshormonal dysplasia; preparations "Zitazonium", "Feliferon", antioxidants.

It is established that the application of the preparation "Zitazonium" in combination with recombinant interferon "Feliferon" gives a lasting clinical effect in $95.65 \%$ of sick cats, without clinical recurrence. In cats with dyshormonal dysplasia, after 2 months of treatment with "Zitazonium" in combination with "Feliferon", as well as in combination with a complex of antioxidants, the sympathetic effects are observed on the heart, which is accompanied by myocardial instability and activation of rhythm heart, as well as impaired hemodynamics of the system type and arrhythmia. Therefore, it is necessary to constantly monitor the indicators of the cardiovascular system in cats treated with "Zitazonium" and "Feliferon" and an antioxidant complex to prevent adverse effects during hormonal therapy.

УДК 636.2.57.089.38

\section{ВЛИЯНИЕ НАНОЧАСТИЦ ВЫСОКОДИСПЕРСНОГО КРЕМНЕЗЕМА НА КРИОРЕЗИСТЕНТНОСТЬ ДЕВИТРИФИЦИРОВАННЫХ ООЦИТ-КУМУЛЮСНЫХ КОМПЛЕКСОВ ВOS TAURUS}

КУЗьМИНА Татьяна Ивановна, Всероссийский научно-исследовательский институт генетики и разведения сельскохозяйственных животных - филиал ФГБНУ «Федеральный научный центр животноводства - ВИЖ имени академика Л.К. Эрнста»

СТАНИСЛАВОВИЧ Татьяна Ивановна, Всероссийский научно-исследовательский институт генетики и разведения сельскохозяйственных животных - филиал ФГБНУ Федеральный научный цеентр животноводства - ВИЖ имени академика Л.К. Эрнста МОЛчАНОВ Алексей Вячеславович, Саратовский государственный аграрный университет имени Н.И. Вавилова

В настоящем исследовании идентифищирован характер воздействия нВДК на показатели криорезистентности соматических (кумулюс), половых клеток (ооциты) овариальных фолликулов коров и оплодотворяемость яйщеклеток. Выявлено положительное действие нВДК на сохранность и функциональное состояние клеток кумулюса после девитрификации и культивирования ооцит-кумулюсных комплексов. Уровень девитрифицированных ооцитов, прокультивированных с 0,001\% нВДК, достигших стадии метафазы ІІ, значительно превышал таковой у девитрифищированных ооцитов, не подвергшихся обработке нВДК (60 \% против 41 \%, P<0,001, $\chi^{2}$-test). При воздействии нВДК на заморожено-оттаянные ооциты значительно повышался выход эмбрионов на стадии бластоцисты (11\% (13/121) против 5 \% (5/105), Р<0,05, $\chi^{2}$-test). Помимо обнаруженных положительных эффектов действия нВДК на морфологию кумулюса и созревание девитрифицированных ооцитов Воs taurus, полученные данные способствуют лучиему пониманию механизмов функиионирования соматических и половых клеток овариальных фолликулов в условиях сверхнизких температур. 
тельные усилия криобиологов и эмбриотехнологов, проблема криорезистентности ооцитов Bos taurus в должной степени не решена [14]. Трудности в разработке эффективной технологии криоконсервации женских гамет обусловлены целым рядом причин, связанных с особенностями строения ооцита, чувствительностью различных клеточных компартментов к воздействию сверхнизких температур, токсичностью криопротекторов [12].

В настоящее время перспективным представляется метод «ультрабыстрого» замораживания женских гамет (витрификация), при котором используются высокие концентрации криопротекторов [6, 9, 13]. Поиск эффективных криопротекторных агентов, позволяющих сохранить целостность клеточных структур и их функциональную активность, а также создание системы для культивирования девитрифицированных клеток - важнейшие задачи современных криотехнологий. Высокодисперсный кремнезем обладает уникальным комплексом физико-химических и медико-биологических свойств: высокой сорбционной емкостью белков, отсутствием аллергенного и токсического воздействия на клетки, активацией репаративных процессов. Модифицированная различными функциональными группами поверхность высокодисперсного кремнезема дает возможность использовать ВДК как матрицу для синтеза материалов с определенными физико-химическими и биологическими свойствами $[2,10]$.

Ранее было выявлено положительное воздействие наночастиц высокодисперсного кремнезема на жизнеспособность декриоконсервированных сперматозоидов быков $[1,8]$, синхронизацию ядерно-цитоплазматического созревания in vitro ооцитов, формирование зигот и дробление эмбрионов свиней до стадии ранней морулы [5]. Таким образом, наночастицы высокодисперсного кремнезема являются перспективными компонентами для оптимизации систем дозревания ооцитов и сред для культивирования соматических и половых клеток овариальных фолликулов и доимплантационных эмбрионов животных.

Цель настоящего исследования - иден- тифицировать характер воздействия наночастиц высокодисперсного кремнезема на показатели криорезистентности соматических (кумулюс) и половых клеток (ооциты) овариальных фолликулов коров.

Методика исследований. Ооцит-кумулюсные комплексы аспирировали из фолликулов диаметром от 2 до 8 мм с высоким тургором, широко разветвленной сетью капилляров и прозрачной оболочкой с помощью иглы для подкожных инъекций. Только ооциты с гомогенной цитоплазмой (по меньшей мере с 5-6 слоями кумулюсных клеток) использовали для культивирования и витрификации. Отобранные ооциты культивировали при температуре $38,5^{\circ} \mathrm{C}$ в атмосфере, содержащей $5 \% \mathrm{CO}_{2}$, в течение 24 ч в среде следующего состава: ТC199 + 10 \% фетальной бычьей сыворотки $+10^{6}$ кл./мл гранулезы + 50 нг/мл пролактина, 10 мкг/мл гентамицина[10]. В опытные группы сред для культивирования добавляли наночастицы 0,001 \% ВДК (марка А200 ${ }^{\circ} \mathrm{C}$, институт химии поверхности им. А.А. Чуйко НАН Украины). В отборе концентраций руководствовались указанными разработчиками и основывались на данных, представленных нами ранее $[1,2,4,5]$.

Витрификацию ооцит-кумулюсных комплексов проводили после их извлечения из фолликулов. Ооциты, предназначенные для витрификации, обрабатывались тремя растворами криопротекторов (КПА), приготовленными на среде ТС-199 с 0,001\%-ми наночастицами ВДК и 10\%-й фетальной бычьей сывороткой (ФБС). КПА-1: 0,7 М диметилсульфоксид (ДМСО)+ $+0,9$ М этиленгликоля (ЭГ); КПА-2: 1,4 М ДМСО + 1,8 М ЭГ; КПА-3: 2,8 М ДМСО + $+3,6 \mathrm{M}$ ЭГ + 0,65 М трегалозы. Ооцит-кумулюсные комплексы поэтапно экспонировали 30 с в КПА-1, затем в КПА-2 и 20 с в КПА-3. Пайеты с ооцитами помещали в жидкий азот. Ооцит-кумулюсные комплексы извлекали из пайет не раньше, чем через 60 мин, и помещали в раствор $0,25 \mathrm{M}$ трегалозы в ТС-199 с 10\%-й ФБС (3 мин) при $37^{\circ} \mathrm{C}$, отмывали в $0,19 \mathrm{M}(3 \mathrm{мин})$, затем в 0,125 М трегалозы (3 мин), окончательно трижды в ТС-199 с 10\%-й ФБС и наночастицами 0,001 \% ВДК. Для контроля за со- 
стоянием хроматина в ооцитах готовили препараты хромосом по методу Тарковского [5]. С этой целью ооциты помещали на 5-10 мин в теплый $\left(37^{\circ} \mathrm{C}\right)$ гипотонический раствор 3-замещенного цитрата натрия (0,9\%-й раствор в дистиллированной воде) и с помощью препаровальной иглы механически очищали от кумулюса. Затем ооциты и клетки кумулюса переносили на сухие обезжиренные стекла, фиксировали смесью метанола и уксусной кислоты (3:1). Высохшие препараты окрашивали по Романовскому - Гимза (азур-эозином) в течение 5-10 мин в зависимости от качества красителя и промывали водой, а затем 70\%-м этанолом.

Образцы суховоздушных препаратов оценивали при увеличении 900× на световом микроскопе. Все использованные в исследовании реагенты, за исключением обозначенных, производства фирмы Sigma-Aldrich. Эксперименты проводили в 3-5 повторностях. Для сравнения результатов использовали критерии $\chi^{2}-$ тест (статистическая программа Sigma Stat). Достоверность различия сравниваемых средних значений оценивали при трех уровнях значимости: $P<0,05 ; P<0,01 ; P<0,001$. Структурно-логическая схема экспериментов представлена на рис.1.

Созревание ооцита млекопитающих высококоординированный процесс, результатом которого является овуляция ооцита, готового к оплодотворению и дальнейшему развитию. Нарушение этого синхронизированного процесса приводит к дегенерации ооцита и его гибели. Взаимодействие между ооцитом и окружающими его соматическими клетками овариального фолликула необходимо как для гаметы, так и для других фолликулярных клеток. Возможность оказывать влияние ооцита на дифференцировку соматических клеток фолликула была показана в paботах J Eppig. и др. [11]. Рост и созревание ооцита in vivo протекает в тесной взаимосвязи с окружающими его клетками кумулюса, образуя структурно-функциональную единицу - ооцит-кумулюсный комплекс.

Эффективность взаимодействия тандема половой и соматических клеток детерминирует завершение фазы роста ооцита, его ядерно-цитоплазматическое созревание, приобретение яйцеклеткой компетен- тности к оплодотворению и дальнейшему развитию сформировавшегося из нее эмбриона. До культивирования кумулюсные клетки плотным гомогенным слоем окружают ооцит, при культивировании клетки кумулюса активно пролиферируют с последующей дифференцировкой, детерминирующей продукцию ими различных биологически активных веществ, обеспечивающих созревание ооцита. В норме морфология кумулюса в динамике культивирования представлена компактным (до культивирования) и разрыхленным (экспандированным) по завершению времени культивирования кумулюсом. Перспективными для культивирования являются ооциты, окруженные не менее чем 5-6 слоями клеток кумулюса, а морфология кумулюса большинства девитрифицированных (заморожено-оттаянных ооцитов) в результате воздействия сверхнизких температур отличается высокой степенью экспансии, таким образом потенции к завершению мейотического созревания ооцитов резко снижаются.

В наших исследованиях проанализирована морфология клеток кумулюса нативных и девитрифицированных ооцитов, подвергшихся воздействию наночастиц ВДК. В зависимости от морфологии кумулюса ооциты ранжировали на три группы: ооциты с высокой, средней и низкой степенью экспансии. После витрификации кумулюс ооцитов, подвергшихся воздействию наночастиц ВДК, сохранял компактность: 71 \% таких ооцитов имели кумулюс с низкой степенью экспансии, в контрольной группе вышеуказанный показатель составил 51 \% $\left(P<0,01, \chi^{2-}\right.$ test, рис. 2).

Максимальная доля ооцитов, окруженных кумулюсом в высокой степени экспан-

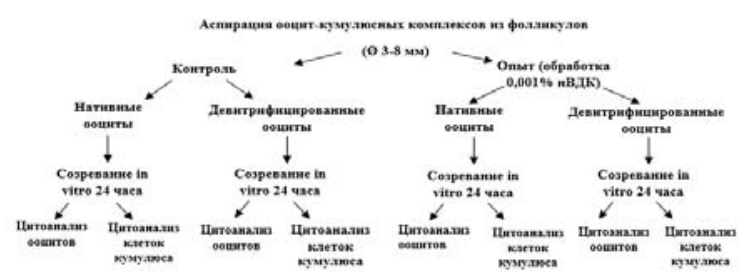

Рис. 1. Оценка криорезистентности ооцит-кумулюсных комплексов Воs taurus при воздействии наночастицами въсокодисперсного кремнезема 
сии, отмечена в группе девитрифицированных ооцитов, не подвергшихся обработке наночастицами ВДК (41 \%). При введении в криопротекторные и культуральные среды наночастиц ВДК доля как нативных, так и девитрифицированных гамет с высокоэкспандированным кумулюсом после культивирования значительно превысила таковую в группе ооцит-кумулюсных комплексов, не подвергшихся воздействию нВДК (91 против $78 \%$, a:b $P<0,01 ; 59$ против $31 \%$, $\left.{ }^{c: d} P<0,001\right)$.

В целом анализ результатов проведенных экспериментов выявил положительное действие нВДК на морфологию кумулюса в процессе культивирования ооцит-кумулюсных комплексов, что косвенно свидетельствовало о завершении ядерно-цитоплазматического созревания самого ооцита. Последнее подтвердилось при цитологическом анализе яйцеклеток (рис. 4).

Уровень девитрифицированных ооцитов, прокультивированных с наночастицами ВДК, достигших стадии метафазы-II, значительно превышал таковой у девитрифицированных ооцитов, не подвергшихся воздействию нВДК (60 против $41 \%$, c:d $P<0,001$ $\left(\chi^{2}\right.$-test)). Таким образом, при использовании наночастиц ВДК в технологиях витрификации и экстракорпорального дозревания ооцитов выявлены их криопротекторные свойства. Эффекты выражались в повышении показателей криорезистентности ооциткумулюсных комплексов - сохранении функциональной активности кумулюса, о чем свидетельствовала динамика морфологичес-

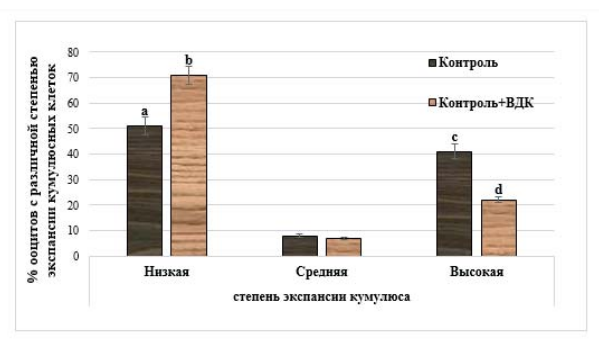

\footnotetext{
Рис. 2. Влияние состава криопротекторов на морфологию кумулюса ооцитов коров после процедуры замораживания/оттаивания (286 ОКК; 3-5 повторностей; a:b;:ac; b:c; c:d $P<0,01\left(\chi^{2-}\right.$ test)); ${ }^{*}$ нВДК - наночастицы высокодисперсного кремнезема
}

ких преобразований и достижение ооцитами завершающей стадии ядерного созревания (метафазы-II).

Ранее нами был выявлен положительный эффект наночастиц ВДК на развитие доимплантационных эмбрионов коров, полученных из нативных ооцитов, созревших в средах, дополненных наночастицами 0,001 \% ВДК [3]. В настоящем исследовании обнаружено, что при воздействии нВДК на заморожено-оттаянные ооциты значительно повышался выход эмбрионов на стадии бластоцисты (11 \% (13/121) против 5 \% (5/105), $P<0,05)$.

Заключение. Витрификация женских гамет - эффективный способ для сохранения генофонда исчезающих пород, решения важнейших проблем репродуктивной медицины, внедрения достижений клеточных репродуктивных технологий в практику животноводства. Проведенные нами исследования направлены на поиск эффективных нетоксичных криопротекторов и сред для дозревания ооцитов.

В представленных материалах обос-
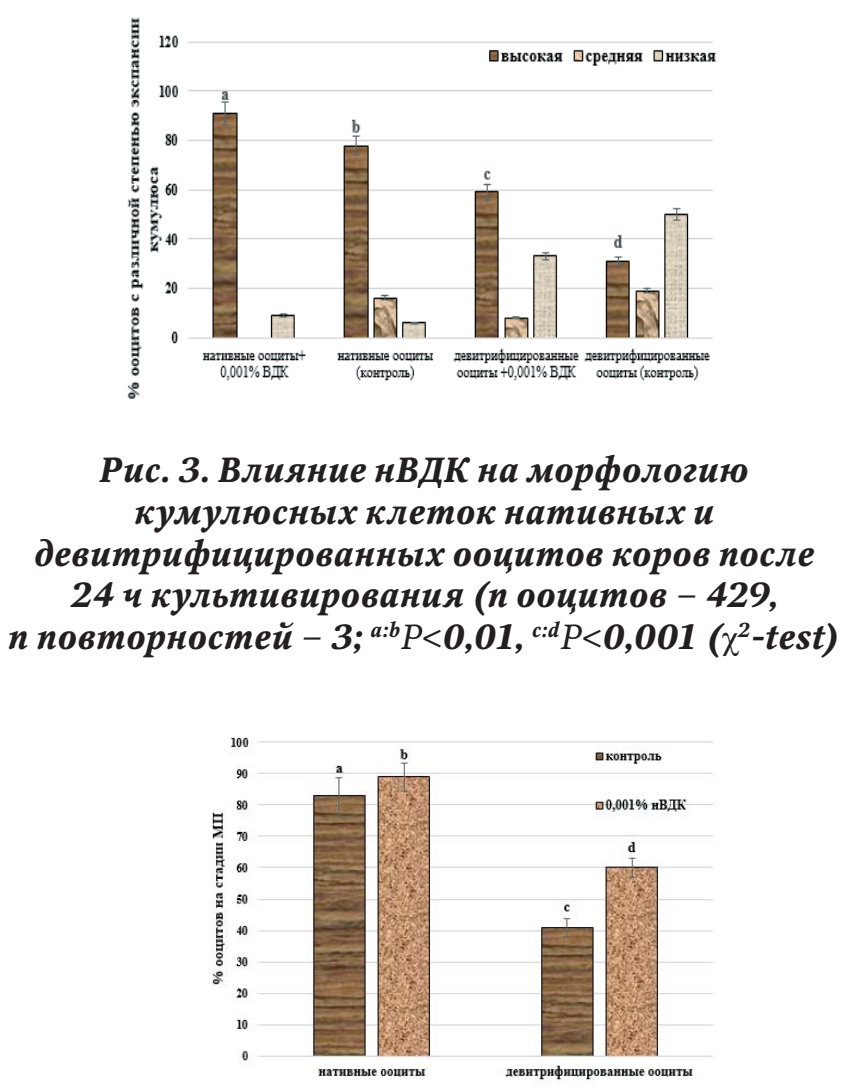

Рис. 4. Влияниен ндК на мейотическое созревание нативных и девитрифищированных ооциитов коров (п ооцитов - 429, п повторностей 4; ${ }^{a: c ; a: d ; b: c ; b: d ; c: d P<0,001}\left(\chi^{2}-\right.$ test $\left.)\right)$ 
новано использование наночастиц высокодисперсного кремнезема в технологии витрификации женских гамет, а именно: не выявлено генотоксичного действия нВДК на ядерное созревание женских гамет, показана возможность получения эмбрионов на стадии бластоцисты из девитрифицированных ооцитов. Помимо идентификации положительных эффектов действия наночастиц высокодисперсного кремнезема на морфологические преобразования кумулюса и созревание девитрифицированных ооцитов Bos taurus полученные данные способствуют лучшему пониманию механизмов функционирования соматических и половых клеток овариальных фолликулов в условиях сверхнизких температур.

Работа выполнена в соответствии с темой Министерства образования Российской Федераиии, номер госрегистрации - АAAAA18-118021590132-9.

\section{СПИСОК ЛИТЕРАТУРЫ}

1. Бойцева Е.Н., Бычкова Н.В., Кузъмина Т.И. Влияние наночастиц высокодисперсного кремнезема на апоптоз сперматозоидов Bos Taurus // Цитология. - 2017. - Т. 59. - № 5. - С. 375-380.

2. Биофункциональные наноматериалы на основе высокодисперсного кремнезема, белка и аминоуглеводов / Н.П. Галаган [и др.] // Biopolymers and Cell. - 2010. Т. 26 (3). - С. 205-213.

3. Воздействие кремнийсодержащих соединений на развитие доимплантационных эмбрионов Bos taurus / И.В. Чистякова [и др.] // Вопросы нормативно-правового регулирования в ветеринарии. - СПб., 2018. С. 105-108.

4. Геращзенко И.И. Мембранотропные свойства наноразмерного кремнезема // Поверхность. 2009. - Вып. 1 (16). - С. 288-306.

5. Застосування наноматеріалу в ембріогенетичній системі in vitro отримання ембріонів свиней / А.Б. Зюзюн [и др.] // Фактори експериментальної еволюції організмів. - 2015. - Т.17. С. $164-168$.

6. Модификация этапов технологии витрификации ооцитов Bos taurus / Т.И. Кузьмина [и др.] // Таврический вестник аграрной науки, - 2017. № 3 (11). - С. 80 -87.

7. Модернизация этапов технологии экстракорпорального созревания донорских ооцитов Bos taurus / Т.И. Кузьмина [и др.] // Аграрный научный журнал. - 2017. - № 3. - С. 9-14.
8. Настасієнко Н.С., Кузема П.О., Галаган Н.П. Дослідження біологічної активності кремнеземів, модифікованих ди-татриметилсілільними групами і сорбітом, повідношенню до сперматозоїді вбиків методом фотон-кореляційної спектроскопії // Фізикаживого. - 2010. - Т. 18. № 3. - C. 99-106.

9. Развитие доимплантационных эмбрионов Bos taurus u Sus scrofa domesticus, полученных из девитрифицированных ооцитов / Т.И. Кузьмина [и др.] // Генетика и разведение животных. - 2014. - № 4. - С. 15-19.

10. Чуйко А.А. Медицинская химия и клиническое применение диоксида кремния. - Киев: Наук. думка, 2003. - 416 с.

11. Eppig John J., Wigglesworth K. and Frank L. Pendola The mammalian oocyte orchestrates the rate of ovarian follicular development // Developmental Biology, 2002, Vol. 99, No. 5, P. 2890-2894.

12. Katkov I.I., Pogorelov A.G. Influence of exposure to vitrification solutions on 2-cell mouse embryos: II. Osmotic effects or chemical toxicity // CryoLetters, 2007, Vol. 28, P. 409-427.

13. Khalili M.A., Shahedi A., Nottola S.A. , Ashourzadeh S., Macchiarelli G., Palmerini M.G., Assist J. Vitrification of human immature oocytes before and after in vitro maturation: a review // Reprod. Genet, 2017, Vol. 34, P. 1413-1426.

14. Paul A.K., Liang Y., Srirattana K., Nagai T., Parnpai R. Vitrification of bovine matured oocytes and blastocysts in a paper container // Anim. Sci. J., 2018, Vol. 89, No. 2, P. 307-315.

15. Tarkowski A. An air-diying method for chromosomal preparation from mouse eggs // Cytogenetic, 1966, Vol.1, P. 394-400.

Кузьмина Татьяна Ивановна, $\partial-p$ биол. наук, проф., зав. лабораторией биологии развития, главный научный сотрудник, Всероссийский научно-исследовательский институт генетики и разведения сельскохозяйственных животных филиал ФГБНУ «Федеральный научный центр животноводства - ВИЖ имени академика Л.К. Эрнста». Россия.

Станиславович Татьяна Ивановна, канд. с.-х. наук, ведущий научный сотрудник лаборатории биологии развития, Всероссийский научно-исследовательский институт генетики и разведения сельскохозяйственных животных - филиал ФГБНУ «Федеральный научный изентр животноводства - ВИЖ имени академика Л.К. Эрнста». Россия.

196625 , г. Санкт-Петербург - Пушкин, Московское шоссе, 55 а.

Тел.: 9214026719; e-mail:1llfor@mail.ru.

Молчанов Алексей Вячеславович, $\partial-p c$. $-x$. наук, проф., зав. кафедрой «Технология производства и переработки продукиии животноводства», 
Саратовский государственный аграрный университет имени Н.И. Вавилова. Россия.

410005, г. Саратов, ул. Соколовая, 355.

Тел.: (8452) 69-25-32.
Ключевые слова: ооцит; in vitro; наночастицы высокодисперсного кремнезема (нВДК); кумулюс; витрификация; Bos taurus.

\title{
EFFECTS OF HIGHLY DISPERSED SILICA NANOPARTICLES ON THE CRYORESISTANCE OF DEVITRIFIED BOS TAURUS CUMULUS-OOCYTE COMPLEXES
}

Kuzmina Tatiana Ivanovna, Doctor of Biological Sciences, Professor, Senior Researcher, All-Russian Research Institute of Genetics and Breeding of Farm Animals - branch of Federal State Budget Scientific Institution "Federal Scientific Center for Animal Husbandry - VIZH named after Academician L.K. Ernst". Russia.

Stanislavovich Tatyana Ivanovna, Candidate of Agricultural Sciences, Leading Re-searcher, All-Russian Research Institute of Genetics and Breeding of Farm Animals - branch of Federal State Budget Scientific Institution "Federal Scientific Center for Animal Husbandry - VIZH named after Academician L.K. Ernst". Russia.

Molchanov Aleksey Vyacheslavovich, Doctor of Agricultural Sciences, Professor, Head of the chair "Technology of Production and Processing of Livestock Product", Saratov State Agrarian University named after N.I. Vavilov. Russia.

Keywords: oocytes; in vitro; highly dispersed silica nanoparticles (HDSns); cumulus; vitrification; BosTaurus.

The creation of the donor oocytes cryobank in agricultural animals will make it possible to significantly improve the introduction of high-tech cellular reproductive and DNA technologies (in vitro production of embryos, cloning, transgenesis, genome editing) into the animal husbandry practice. Despite the considerable efforts of cryobiologists and embryotechnologists, the problem of Bos Taurus oocyte cryoresistance has not been adequate- ly solved. The search for effective cryoprotective agents (CPA) that preserve the integrity of cellular structures, their functional activity and the creation of a system for the cultivation of devitrified cells are the most important tasks of modern cryotechnologies. Highly dispersed silica nanoparticles (HDSns) are promising componentsfor optimizing CPA systems and media for cultivating somatic and germ cells of ovarian follicles, as well as pre-implantation embryos of animals. In the present study the nature of the effect of HDSns on the somatic (cumulus), germ cells (oocytes) of ovarian cow follicles and the fertility of the ova was identified. The positive effects of HDSns on the safety and functional state of cumulus cells after devitrification and cultivation of cumulus - oocyte complexes were shown. The level of devitrified oocytes that have cultured with $0.001 \%$ of HDSns and have reached the metaphase II, significantly exceeded the level of matured devitrified oocytes that have not treated with HDSns (60\% vs. $41 \%, P<0.001$ (2-test)).The yield of embryos at the blastocyst stage significantly increased when devitrified oocytes were cultured with HDSns (11\% (13/121) vs. 5\% (5/105), $P<0.05)$. In addition to the observed positive effects of the HDSns on the cumulus morphology and maturation of devitrified Bos Taurus oocytes, the data obtained contribute to a better understanding of the mechanisms of functioning of somatic and germ cells from ovarian follicles under ultralow temperatures.

\section{ВЛИЯНИЕ РАЗНЫХ УРОВНЕЙ МЕДИ НА ПЕРЕВАРИМОСТЬ ПИТАТЕЛЬНЫХ ВЕЩЕСТВ РАЦИОНА ЛАКТИРУЮЩИМИ ОВЦЕМАТКАМИ}

\author{
МАНДЖИЕВ Дмитрий Борисович, Национальный исследовательский Мордовский \\ государственный университет имени Н.П. Огарева
}

ГАЙИРБЕГОВ Джунайди Шарамазанович, Национальный исследовательский

Мордовский государственный университет имени Н.П. Огарева

В физиологических опытах изучено влияние различных уровней меди в рационах на переваримость питательных веществ лактирующими овцематками.

Введение. На физиологические процессы, протекающие в организме животных, оказывают влияние различные факторы: корма, их питательная ценность, наличие необходимых элементов питания, их соответствие рекомендуемым нормам [2, 6, 7]. Доказано, что жизне- деятельность микрофлоры рубца и метаболизм жвачных животных протекают нормально только тогда, когда с рационом поступают качественные сочные корма, а также определенное и эквивалентное количество минеральных веществ [4, 10-12]. 